\title{
WILD SUNFLOWERS RESEARCH IN ARGENTINA
}

Poverene M. ${ }^{1,2}$, Cantamutto M.A. ${ }^{1,3}$, Carrera A. ${ }^{1}$, Ureta S. ${ }^{2}$, Alvarez D. ${ }^{4}$, Alonso Roldán V. ${ }^{1}$, Presotto A. ${ }^{2}$, Gutiérrez A. ${ }^{2}$, Luis S. ${ }^{5}$, Hernández A. ${ }^{5}$

${ }^{1}$ Dept. of Agronomy, Universidad Nacional del Sur, Bahía Blanca, Argentina, ${ }^{2}$ CERZOS-CONICET, Bahía Blanca, Argentina,

${ }^{3}$ Centro UdL-IRTA, Lleida, España,

${ }^{4}$ EEA INTA Manfredi-Argentina

${ }^{5}$ Dept. of Mathematics, Universidad Nacional del Sur, Bahía Blanca, Argentina

Received: September 10, 2005 Accepted: March 25, 2006

SUMMARY

Since 2000 a research is in progress on wild sunflowers in Argentina, comprising naturalized $H$. annuus and $H$. petiolaris populations, and their relationship with cultivated sunflower. The study includes morphological, phenological, biochemical and molecular aspects, addressed to explain dispersal and adaptive processes and gene flow within sunflower crop. We present here a summary of results obtained during the last five years.

Key words: sunflower, wild species, gene flow, hybridization, phenotypic characterization.

\section{INTRODUCTION}

Two wild annual sunflower species, Helianthus annuus and $H$. petiolaris, were introduced in Argentina about 50 years ago and they became naturalized. Although the introduction events are unclear there were probably several entries, possibly as gene source for sunflower breeding and as contaminants in forage seed lots (Bauer 1991; Bertero and Vazquez 2003; A. Luciano, personal communication). However, it was not until seed companies became interested in the release of genetically modified (GM) sunflower varieties that wild relatives caught the attention of the National Committee of Agricultural Biotechnology (CONABIA) in Argentina. In fact, information about the risks of transgene escape and eventual environmental impact are required before any GM crops could be released. This study started with the aim of gathering information for CONABIA in January 2000. We present herein a survey of our research in wild sunflowers, as it was presented at the $10^{\text {th }}$ FAO Consultation Meeting, Novi Sad, Serbia and Montenegro, in July 2005. 


\section{MATERIALS AND METHODS}

As we survey several aspects of the research, indications of materials and techniques are merged with results. Details can be obtained from the referenced papers or from the authors.

\section{RESULTS AND DISCUSSION}

\section{Plant exploration for wild Helianthus species}

Between 2000 and 2005, 28 field collection trips were successfully completed. The species of interest spread over seven provinces of Argentina. The area extends over the central part of the country, between $31.3^{\circ}$ and $38.7^{\circ} \mathrm{S}$ latitude, $60.6^{\circ}$ and $68.3^{\circ} \mathrm{W}$ longitude (Figure 1).

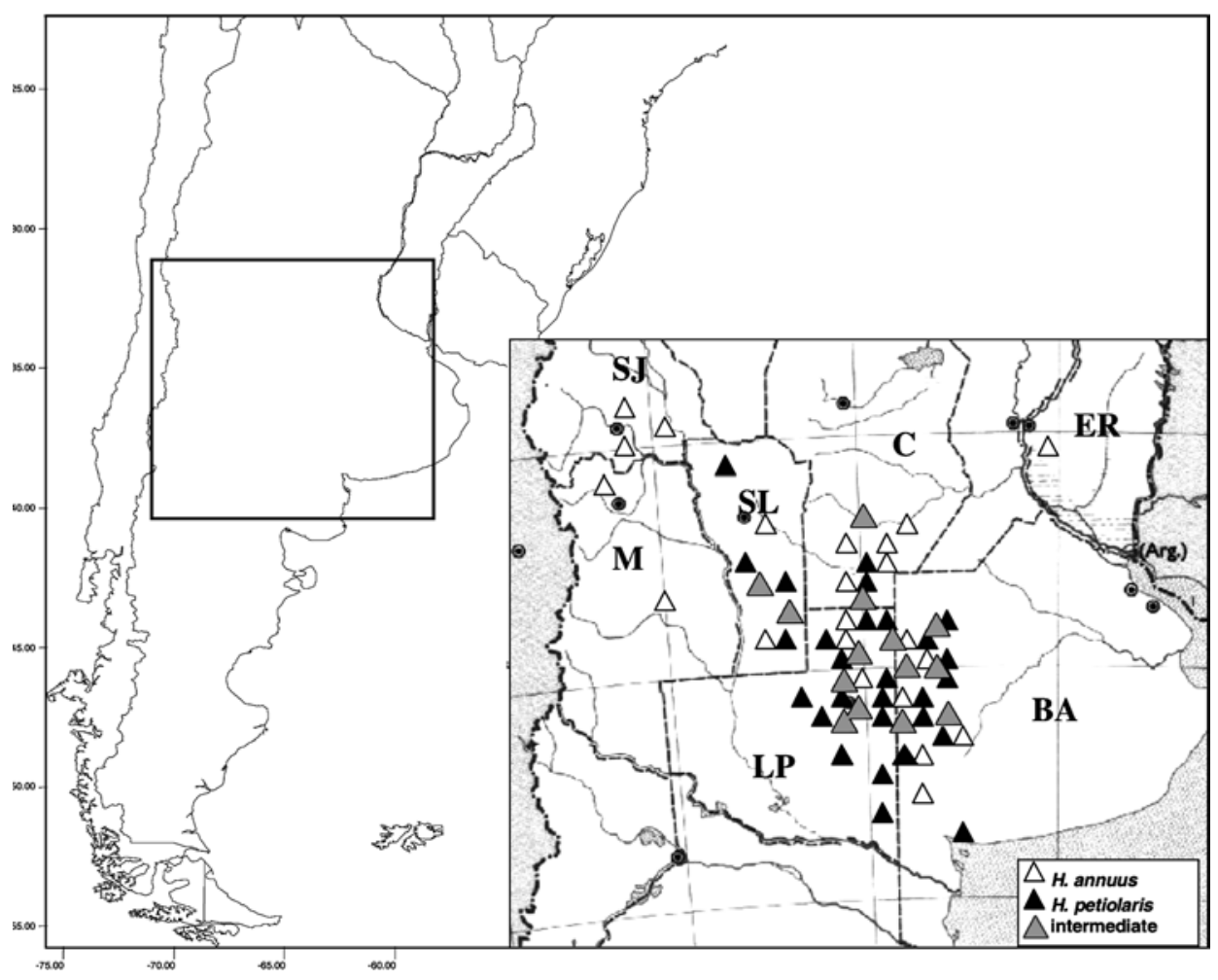

Figure 1: Wild sunflowers distribution in central Argentina, provinces of Buenos Aires (BA), La Pampa (LP), Cordoba (C), Entre Rios (ER), San Luis (SL), Mendoza (M) and San Juan (SJ). Each triangle marks a provincial county where the species is present.

Individuals of both species are mostly encountered in patches along roadsides and disturbed soils (Poverene et al. 2002). Helianthus annuus and H. petiolaris sometimes invade summer crops although not as frequently as in North America. 
Because of the invasions into crops they may be considered weeds in the core zone of the sunflower crop.

Helianthus annuus grows in a wide range of habitats and soils, from eastern Entre Rios to western Mendoza and San Juan provinces, with the largest populations located in Cordoba. $H$. petiolaris is more restricted to sandy soils of central La Pampa and the borders of Buenos Aires and San Luis provinces. Both species grow on Mollisols; $H$. annuus is frequently found on Argiaquolls while $H$. petiolaris populations grow on Haplustolls. Both species show large variation in soil order and suborder preference, mostly on soils subjected to eolic erosion.

A comparison of climate parameters made with 31 Argentinean and 46 US localities representing the span of wild $H$. annuus populations showed that the geographic range of US populations was almost four times larger than the range for Argentinean populations. Thirty-one stable populations, found in two or more successive years were localized by GPS positioning. Site variables on altitude, annual rainfall, and mean temperature were estimated based on the nearest locality (De Fina 1992). Those were compared with 993 accessions of 39 US states from GRINUSDA germplasm bank (www.ars-grin.gov2/cgi-bin/npgs/html) grouped in 46 localities for which climate data were taken from www.worldclimate.com (Cantamutto et al. 2005). Highly significant differences were found in latitude and altitude distribution between the two countries (Table 1). Although the mean temperature of the colder month was lower for the US sites compared with the Argentinean sites, there were no significant differences in the mean temperature of the warmest month and the mean annual rainfall. The wider span of the occupied area in the center of origin with respect to Argentina may indicate that the expansion process of exotic wild sunflowers is likely to continue. In fact, successive explorations indicate a continual expansion of the colonized area.

Table 1: Site climate variables for H. annuus annuus L. populations in North America and Argentina

\begin{tabular}{lcc}
\hline & North America & Argentina $^{1}$ \\
\hline Latitude $\left(^{\circ}\right)$ & $39.7 \pm 5.4 \mathrm{~N}$ & $34.1 \pm 1.6 \mathrm{~S} * *$ \\
Altitude $(\mathrm{m} \text { a. S. I. })^{2}$ & $701 \pm 478$ & $266 \pm 195 * *$ \\
Annual rainfall $(\mathrm{mm})$ & $514 \pm 329$ & $614 \pm 240 \mathrm{~ns}$ \\
Warmest month mean temperature $\left(\mathrm{C}^{\circ}\right)$ & $28.8 \pm 3.3$ & $24.3 \pm 0.9 \mathrm{~ns}$ \\
Coldest month mean temperature $\left(\mathrm{C}^{\circ}\right)$ & $-1.8 \pm 7.2$ & $8.5 \pm 1.3 * *$ \\
\hline
\end{tabular}

${ }^{1}$ Significant at the 0.01 level. ${ }^{2}$ Meters above sea level.

Gene flow between the two wild species and the cultivated sunflower is evidenced by intermediate forms often found in wild populations and tilled lands. Hybridization and introgression might have shifted genetic variation in Argentinean populations that may now differ from variation at the center of origin. At present, our collection has $135 \mathrm{H}$. petiolaris and $90 \mathrm{H}$. annuus accessions plus samples from over 20 localities where hybrid forms are common. Seed samples of $17 \mathrm{H}$. annuus and $18 \mathrm{H}$. petiolaris accessions were kindly supplied in 2004 by the USDA- 
Table 2: Morphological and phenotypic characters used for statistical analysis of wild Helianthus annuus. Underlined traits were used as descriptors for the INTA germplasm bank.

\begin{tabular}{|c|c|}
\hline 1. Plant characters & S. bataticola \\
\hline Anthocyanin in hypocotyl & Drought tolerance \\
\hline Stem pubescence & Lodging \\
\hline Branching type & 5. Flowering characters \\
\hline Presence of main head & Leaves at head back \\
\hline Plant height & Number of ray flowers \\
\hline Stem diameter at medium height & Ray color \\
\hline Head position & Ray width \\
\hline Head number & Ray length \\
\hline 2. Leaf characters at medium height & Phyllary number \\
\hline Leaf width & Phyllary disposition (oppressed, loose) \\
\hline Leaf length & Phyllary tips (acute, acuminate) \\
\hline Leaf size $(\mathrm{WxL})$ & Phyllary pubescence \\
\hline Petiole length & Phyllary length \\
\hline Leaf blade/petiole index & Phyllary basal width \\
\hline Leaf base & Phyllary L/W ratio \\
\hline Leaf shape & Pappus presence \\
\hline Leaf hairs appearance & Pale length (relative to flowers) \\
\hline Leaf surface appearance & Pale pubescence \\
\hline Leaf hair coverage & Pale lobes \\
\hline Leaf margin & Pale anthocyanin presence \\
\hline Leaf number & Stigma anthocyanin presence \\
\hline Leaf shape variation along stem & Head diameter \\
\hline Leaf arrangement (opposite, alter) & Disc flower colour \\
\hline Anthocyanins is stem and petioles & Disc white hairs (presence/ absence) \\
\hline 3. Plant cycle characters & 6. Seed yield characters \\
\hline Days from transplant to $10 \%$ flowering & Seeds from selfing \\
\hline Days from $10 \%$ to $50 \%$ flowering & Seeds from open pollination (OP) \\
\hline Days from transplant to end flowering & 100 OP-seed weight \\
\hline Date of transplant & Hull percentage \\
\hline Number of plants after transplant & Achene length \\
\hline 4. Disease characters & Achene width \\
\hline Downy mildew & Achene shape \\
\hline Leaf rust & Achene color \\
\hline Stem rust & Achene design (striate, maculate) \\
\hline Alternaria, leaf Phoma & Achene pubescence \\
\hline Verticillium & Mottles in pericarp \\
\hline Stem Phoma & Seed set \\
\hline Sclerotinia & \\
\hline
\end{tabular}


ARS North Central Regional Plant Introduction Station, Ames, Iowa, through Dr. Gerald Seiler, covering a broad range of variability. A comparative analysis on morphology and molecular characters is in progress and should provide information about the origin and variability of Argentinean populations. Besides, there are wild entries from the center of origin in North America at germplasm banks, comprising annual and perennial species, at two experiment stations of the National Institute of Agricultural Research of Argentina (INTA).

\section{Phenotypic characterization of wild sunflower species}

Both naturalized species display phenotypic diversity and differences in phenology, though not representing the extreme variability found in North America. Argentinean materials correspond to the taxa $H$. annuus ssp. annuus and $H$. petiolaris ssp. petiolaris, as described by Heiser (1954, 1961). Both species showed significant differences among populations for a number of morphological traits when analyzed by ANOVA and Kruskal-Wallis comparisons. Overall phenotypic similarity among populations was assessed by principal component analysis (PCA). No definite clusters were found for $H$. petiolaris. In addition, no correlation with geographic distribution was apparent in this species although the amount of variation was higher in the populations found in regions of traditional sunflower crop production (Poverene et al. 2004a). Plant cycle was correlated with geographic position (latitude and longitude) and bract (phyllary) width, one of the traits that are frequently influenced by gene flow from the crop. A founder effect was not evident. Although we were not able to find hints about the species' spread over the country, data indicate that several simultaneous introduction events had occurred (Poverene et al. 2004b). In addition, seed dispersion may also be influenced by truck and train movement during sunflower harvest and transport.

On the other hand, multivariate analysis of $H$. annuus did reveal population clusters that allow us to make inferences about the dispersion processes. Traits like plant height and branching, plant cycle, leaf size and shape, and seed set were highly variable among accessions.

Five out of the largest Argentinean wild $H$ annuus populations were compared with 17 North American populations from Kansas, Illinois, Utah, California, New México, South Dakota, North Dakota, Indiana, Iowa, Colorado, Montana, Wyoming, Arizona, Oklahoma, Texas, Nevada and Nebraska, on the grounds of morphology, phenology and disease symptoms. The aim of this study was to assess processes of introduction and diffusion of this species in Argentina. A common garden experiment was performed to gather data on 71 characters (Table 2) (Presotto et al. 2005). Principal component analysis showed that Argentinean populations comprise only a part of the North American variability, but also differentiation processes have taken place during naturalization (Figure 2).

In the summers of 2003 and 2004, nine accessions of wild H. annuus were grown in the experiment field at our Agronomy Department. Seeds regenerated 
from pollination among 30 heads were incorporated into INTA Manfredi Experiment Station active germplasm bank. These constituted the first Argentinean wild materials officially preserved. Descriptors used for population characterization are included in Table 2.

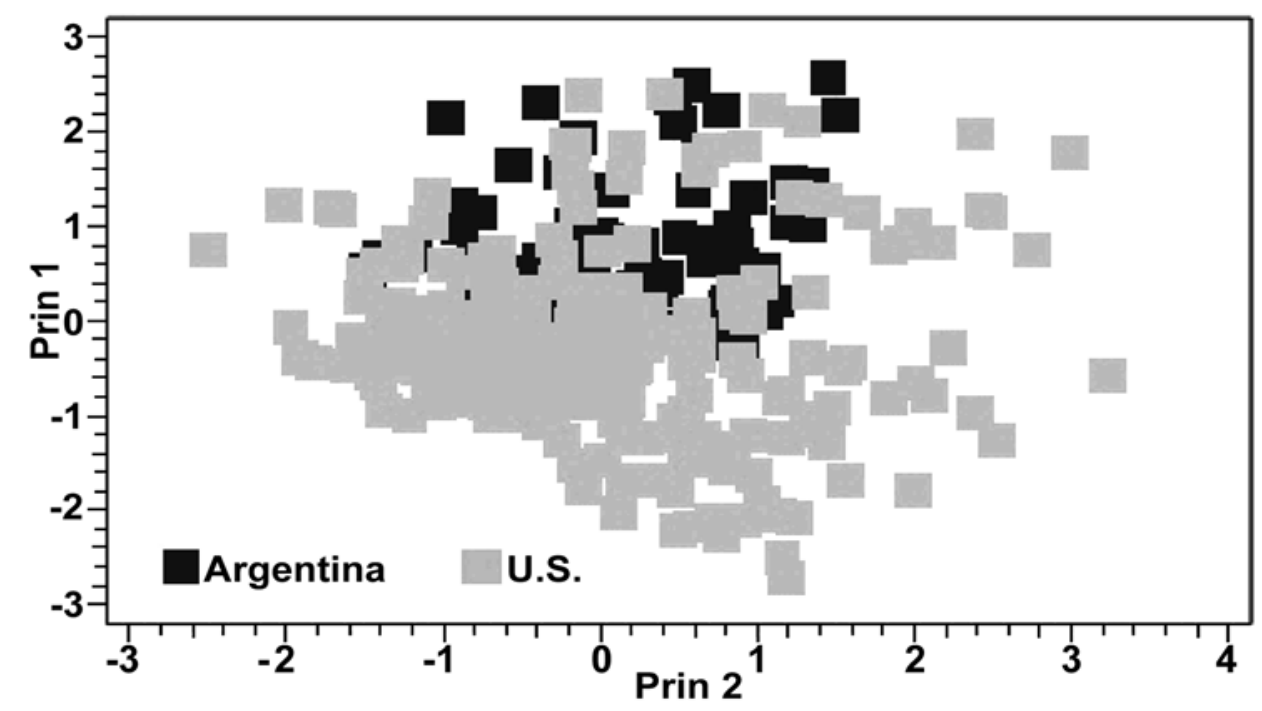

Figure 2: Principal component analysis of wild Helianthus annuus accessions from US and Argentina, based on 71 morphological and phenological traits of Table 2.

Naturalized wild $H$. annuus populations display some promising traits in view of breeding new sunflower cultivars. Accessions grown in the common garden experiment showed differences in susceptibility to Verticillium wilt (Verticillium dahliae), downy mildew (Plasmopara halstedii) and rust (Puccinia helianthi). At this time we are investigating other characters, such as variation in fatty acid composition and life cycle, resistance to diseases, presence of male sterility and tolerance to imazapyr herbicides. In particular, the recent release of imazapyr-tolerant sunflower cultivars in Argentina might have a high impact on wild populations, through hybridization and gene flow.

H. petiolaris populations display high resistance to most fungus diseases. Additionally, in the western Buenos Aires and eastern La Pampa provinces, a region of intensive sunflower production, we have observed tolerance or escape of some $H$. petiolaris individuals to the parasitic plant Cuscuta indecora var. longisepala (Cuscutaceae), which causes severe damage to different crops. This fact may deserve attention, because resistance genes might be implicated.

\section{Oilseed quality}

Fatty acid composition was studied in the largest wild $H$. annuus populations in Argentina. Seed was collected at nine localities and grown in a common garden in 


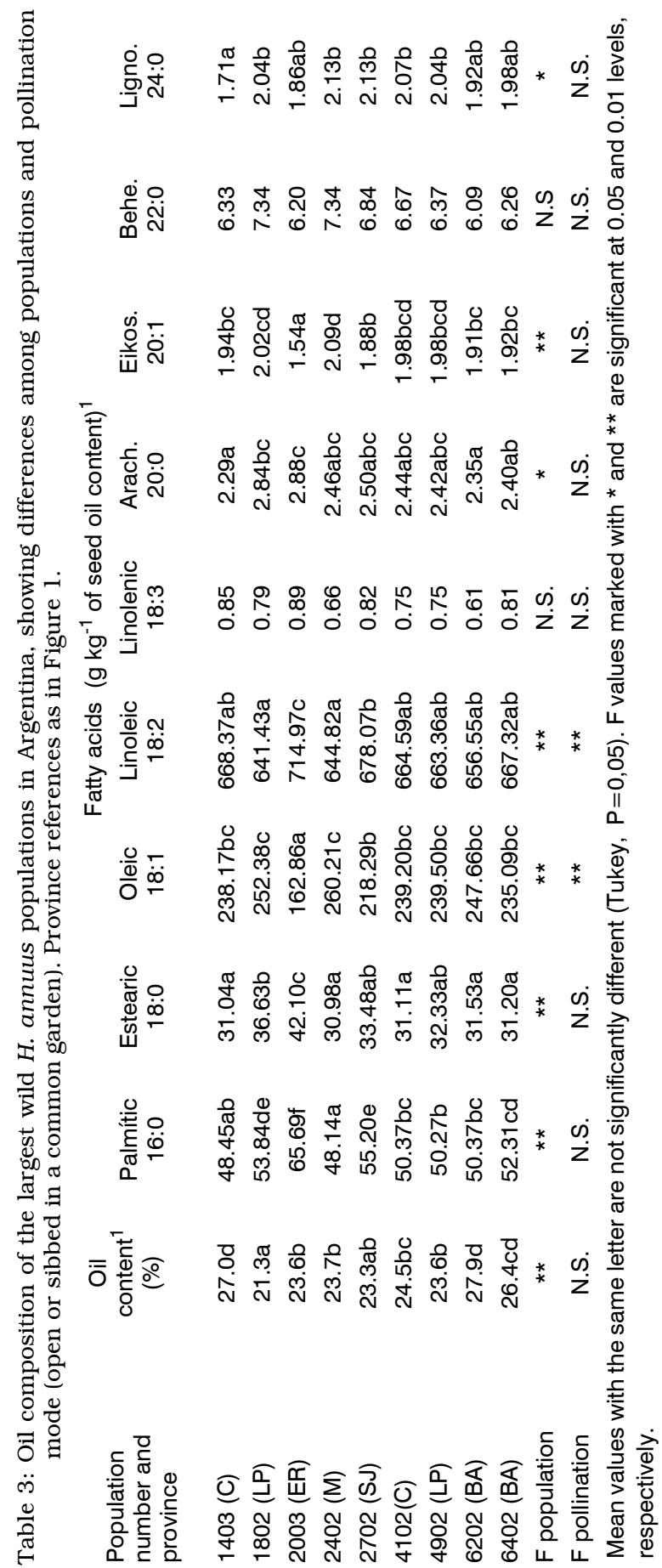


the experiment field. Seed samples from those localities were sown in a randomized design with two replicates. Both open pollinated seed and seed from sib mating were collected from the plants. In this way we were able to compare seeds coming from three sources: each population site in the wild, open pollinated and sibbed in a common garden. We compared oilseed content and fatty acid composition among accessions and also between pollination modes. A $30 \mathrm{~g}$ sample of seed of each accession under the three conditions was analyzed by HPLC. Results were compared with oilseed content and composition of 85 US populations assessed by NMR and gas chromatography, obtained from GRIN-USDA http://www.ars-grin.gov2/cgibin/npgs/html. One-way ANOVA and Tukey test were performed using the SAS statistical package. Highly significant differences among populations were detected for oilseed content, palmitic and stearic acid content and also in minor fractions (Table 3 ). We found that oilseed content was higher in plants growing in the common garden conditions compared with those in the wild $(\mathrm{P}<0.05)$. However, no differences in total oil content were found between open pollinated and sibbed seeds collected in the common garden. Populations showed highly significant differences in most fatty acid fractions, though no differences were found between pollination modes, except for oleic and linoleic acids. Differences in oilseed content may be associated with differences in growing conditions, especially those related to soil water availability. Oilseed variability in local populations was lower than in US populations (Seiler and Brothers 2000). Nonetheless, variability seems to be sufficient to consider local wild resources of interest for breeding purposes.

\section{Molecular diversity}

Molecular analysis revealed high levels of polymorphism in both wild species. Genetic differentiation for RAPD markers among $H$. petiolaris populations assessed by ANOVA showed significant variation both among and within populations. This would indicate a low gene exchange among populations, possibly related to their patchy distribution. As it could be expected, the populations showing higher morphological variation also showed higher molecular diversity. Cluster analysis performed on molecular data based on Dice index grouped $H$. petiolaris populations in two clusters. Notoriously, populations included in one of the clusters had previously evidenced crop hybridization, since a number of plants showing intermediate morphology had been found within them the year before. Thus, the molecular pattern proved useful to demonstrate gene flow and introgression from the crop.

Table 4: Diversity parameters in $H$. annuus populations in the center of origin, wild and cultivated sunflower in Argentina: polymorphic loci (P), mean number of alleles per locus $(\mathrm{A})$ and mean expected heterozygosity $(\mathrm{H})$

\begin{tabular}{lccc}
\hline Populations & $\mathrm{P}$ & $\mathrm{A}$ & $\mathrm{H}$ \\
\hline Wild $H$. annuus in the US & \\
Wild $H$. annuus in Argentina & 0.56 & 1.65 & 0.21 \\
Cultivated inbred lines and hybrids $^{2}$ & 0.43 & 1.60 & 0.17 \\
\hline
\end{tabular}

${ }^{1}$ From Cronn et al. $1997 ;^{2}$ From Carrera et al. 2002. 
Isozymes and SSR analysis revealed high genetic variability in local populations of wild $H$. annuus. Table 4 shows isozyme variability parameters for wild and cultivated sunflower. Measures of genetic variation were slightly lower than those reported for the center of origin (Cronn et al. 1997) showing that populations have not been subjected to strong diversity reduction during the introduction process. The presence of different unique alleles over the whole range of distribution does not agree with the single origin hypothesis of wild $H$. annuus in Argentina and it could rather suggest multiple introductions events.

Allelic composition for 29 microsatellite (SSR) loci of wild and cultivated sunflower was similar. Even so, cultivated sunflower has a subset of alleles. These results are in agreement with a wild ancestor-crop derivative relationship. The high value of average allele number points to the wild populations as important reservoir of genetic variability. Allele frequencies varied between populations, allopatric and sympatric with sunflower crop. Difference in number of plants harboring alleles from the crop was highly significant $(\mathrm{P}<0,005)$ (Figure 3 ).

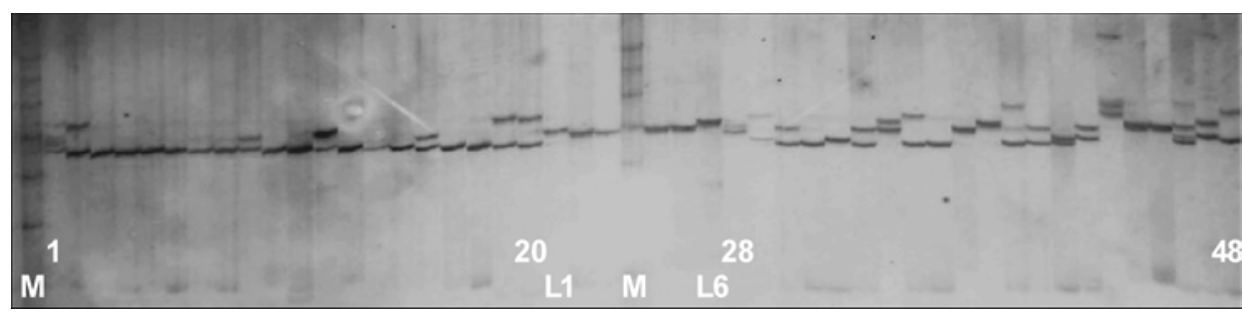

Figure 3: SSR analysis in wild H. annuus populations, allopatric (lanes 1-20) and sympatric (lanes 28-48) with sunflower crop. Central lanes show ladder (M) and sunflower inbred lines ( $L 1$ to L6).

We have not been able to find specific SSR markers for cultivated sunflower yet. It is possible that the isozyme and microsatellite alleles shared by wild and crop plants might represent common genome zones for Helianthus annuus. Alternatively, it could be suggested that the wild populations might have been under crop genetic flow in their native land, before their introduction to Argentina.

\section{Interspecific hybridization and gene flow}

Plants of intermediate morphology are often found in wild populations of both H. annuus and H. petiolaris (Poverene et al. 2004a). Head diameter, bract (phyllaries) width, leaf size and branching make hybrid plants conspicuous enough among wild type ones to indicate a likely $\mathrm{F}_{1}$ hybrid origin. Additionally, these characters point out the cultivated sunflower as the putative parent. One of the characters also notorious in hybrid plants was seed size. We performed an analysis of a sample of plants with the above mentioned characteristics and their families in a common garden study and we were able to confirm the suspected hybrid status. Backcrosses or advanced hybrid generations are not as easily recognized based on morphological traits. Therefore, molecular marker analysis would be necessary to reliably esti- 
mate hybridization. Gene flow from the crop to the two wild species was also estimated by sampling mature heads of wild plants which had flowered at the same time of a close sunflower crop. The progenies were analyzed both for morphological traits and molecular markers. Moreover, gene flow from the wild species to the crop was also confirmed.

Hybrid plants were identified based both on morphology and molecular markers in H. petiolaris populations. RAPD markers showed unique bands for crop and wild plants (Figure 4). The hybrid individuals showed a combination of parental bands, although a petiolaris-like molecular phenotype was also frequent among the hybrids. The unique bands observed in cultivated sunflower constitute potential useful markers to estimate gene flow.

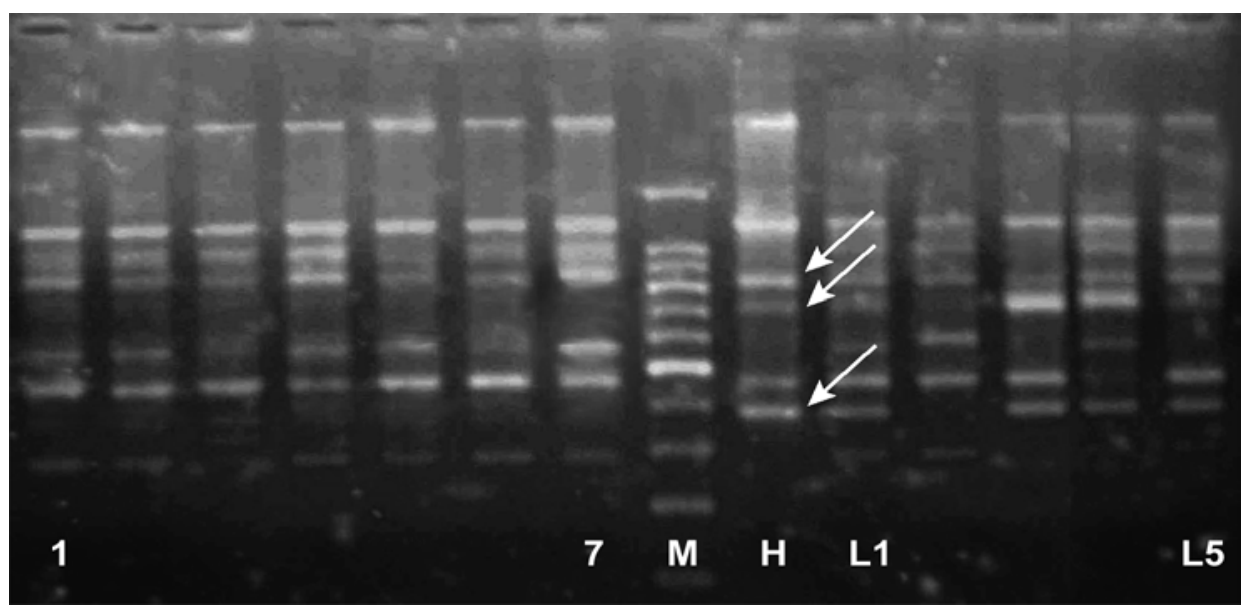

Figure 4: RAPD analysis of $H$. petiolaris plants (lanes 1-7), a natural wild $x$ crop hybrid $(H)$ and sunflower inbred lines used as testers (L1-L5). Arrows show markers bands from the crop (Operon primer A2, M is a $100 \mathrm{bp}$ ladder).

\section{Ongoing work}

Gene flow from IMI sunflowers to wild populations. Screening for imidazolinone resistance in wild populations and pollination of wild $H$. annuus plants with an IMI (Clearfield $\left.{ }^{\circledR}\right)$ sunflower cultivar are currently under way. The aim of this project is to study the influence of this trait in wild sunflowers, searching for molecular markers and changes in population composition and fitness, through survival and fecundity parameters.

Male sterility in Helianthus annuus ssp annuus local populations. Male sterile plants found in the 2003-2004 experiment field were sibbed with normal plants on the same plot. The $\mathrm{S}_{1}$ plants grown in 2004-2005 showed complete recovery of fertility. Heads of those plants were either self-fertilized or subjected to diallelic crosses. We will evaluate fertility in the next generation and compare it with other male-sterility sources. The restoration of PET-1 source will be evaluated in the crosses with MS HA89 and A10 registered lines. 
Characterization and fitness of sunflower crop - $\boldsymbol{H}$. petiolaris hybrids. Crop genes beyond the $F_{1}$ generation following hybridization and the establishment of crop genes in wild populations are being investigated through molecular markers. Crop-wild hybrids fitness is compared with wild plants fitness as a component of determining the risk of transgene escape. Advanced generation hybrids and backcrosses to wild plants are under study in a number of populations where natural $\mathrm{F}_{1}$ hybrids have been found.

Molecular comparison of US and Argentinean materials. We are currently investigating other molecular markers in H. annuus, RAPD and ISSR (DNA polymorphisms based on amplified fragments primed by microsatellite sequences). We hope that they will render more informative markers to estimate crop-wild hybridization. We have already identified some useful markers to study gene flow from the crop to $H$. petiolaris populations, but we need to screen a higher number of populations in order to confirm the validity of this approach.

Combining ability of local Helianthus annuus ssp. annuus populations. During the summer 2004-2005 we crossed two male-sterile lines (A89 and A10) with plants from five Argentine populations of $H$. annuus ssp annuus. Scant seed was obtained, so that it was necessary to repeat the crossing the following summer. The $F_{1}$ seed will be planted in regional evaluations of the sunflower crop area. Agronomic traits such as life cycle, vigor, plant architecture, disease resistance and yield will be evaluated in different crop conditions in order to assess potential value for breeding.

\section{ACKNOWLEDGEMENTS}

This research was promoted by the National Committee of Agricultural Biotechnology (CONABIA). The funding was initially provided by seed companies (Advanta, Monsanto, Mycogen, Novartis and Pioneer) and then through grants of the National Agency for Scientific Promotion (ANPCYT PICT 08-9881) and Universidad Nacional del Sur.

\section{REFERENCES}

Alonso Roldán, V., Carrera, A., Poverene, M., 2004. Variación molecular en poblaciones de Helianthus petiolaris en la Argentina. Actas $33^{\circ}$ Congreso Argentino de Genética. Basic and Applied Genetics XVI (Supplement): pp. 142.

Bertero de Romano, A. and A.N. Vazquez, 2003. Origin of the Argentine sunflower varieties. Helia 26: 127-136.

Bauer, H.A., 1991. Cuarenta años de mejoramiento del girasol (Helianthus annuus L.) en Argentina -1947-1987. Helia 14: 63-68.

Cantamutto, M., Presotto, A., Poverene, M., 2005. Caracterización climática de poblaciones argentinas de Helianthus annuus annuus. $3^{\circ}$ Congreso Argentino de Girasol ASAGIR, Buenos Aires (www.asagir.org.ar)

Carrera, A., Pizarro, G., Poverene, M., Feingold, S., Berry, S., León, A., 2002. Variability among inbred lines and RFLP mapping of sunflower isozymes. Genetics and Molecular Biology 25: $65-72$. 
Cronn, R., Brothers, M., Klier, K., Bretting, P.K., Wendel, J.F., 1997. Allozyme variation in domesticated annual sunflower and its wild relatives. Theor Appl Genet 95: 532-545.

De Fina, A., 1992. Aptitud Agroclimática de la República Argentina. Academia Nacional de Agronomía y Veterinaria, Buenos Aires, pp. 402.

Heiser, C.B.Jr., 1954. Variation and subspeciation in the common sunflower, Helianthus annuus. The American Midland Naturalist, 51: 287-305.

Heiser, C.B.Jr., 1961. Morphological and cytological variation in Helianthus petiolaris with notes on related species. Evolution 15: 247-258.

Poverene, M.M., Cantamutto, M.A., Carrera, A.D., Ureta, M.S., Salaberry, M.T., Echeverria, M.M., Rodriguez, R.H., 2002. El girasol silvestre (Helianthus spp.) en la Argentina: Caracterización para la liberación de cultivares transgénicos. Revista de Investigaciones Agropecuarias (Arg) 31: 97-116.

Poverene, M., Carrera, A., Cantamutto, M., Ureta, S., Delucchi, C., Alonso Roldan, V., Basualdo, J., 2004a. Helianthus petiolaris in Argentina and spontaneous hybridization with cultivated sunflower. $16^{\mathrm{th}}$. International Sunflower Conference, Fargo ND USA Vol. II: 741-746.

Poverene, M., Carrera, A., Ureta, S., Cantamutto, M., 2004b. Wild Helianthus species and wildsunflower hybridization in Argentina. Helia 27: 133-142.

Presotto, A.D., Cantamutto, M.A., Errazu, P., Mendiberri, C., Luis, S., Hernández, A., Poverene, M., 2005. Relación fenotípica entre poblaciones argentinas y norteamericanas de Helianthus annuus ssp. annuus Actas $34^{\circ}$ Congreso Argentino de Genética. Basic and Applied Genetics XVI (Supplement): pp. 180.

Seiler, G.J. and Brothers, M.E., 2000. Comparison of oil quality characteristics of achenes from original and regenerated populations of wild sunflower species. Proc $15^{\text {th }}$ International Sunflower Conference I: A37-42.

\title{
INVESTIGACION SOBRE GIRASOLES SILVESTRES EN ARGENTINA
}

\author{
RESUMEN
}

Desde 2000 se lleva a cabo una investigación sobre girasoles silvestres en Argentina, que comprende las poblaciones naturalizadas de $H$. annuus y $H$. petiolaris y su relación con el cultivo de girasol. El estudio abarca aspectos morfológicos, fenológicos, bioquímicos y moleculares, tendientes a explicar los procesos de dispersión, adaptación y flujo génico con el girasol cultivado. Se presenta aquí un resumen de los resultados obtenidos en los últimos cinco años.

\section{RECHERCHE SUR LE TOURNESOL SAUVAGE EN ARGENTINE}

\section{RÉSUMÉ}

Depuis 2000 des recherches sur le tournesol sont en cours en Argentine. Elles incluent les populations naturalisées $H$. annuus et $H$. Petiolaris et leur rapport envers le tournesol cultivé. Les observations comprennent les aspects morphologiques, phénologiques, biochimiques et moléculaires et elles ont pour but d'expliquer les processus de dispersion et d'adaptation ainsi que l'écoulement de gène dans la culture du tournesol. Nous présentons un résumé des résultats obtenus au cours des cinq dernières années. 